https://doi.org/10.52058/2786-4952 -2021-5(5)-593-605

Тубичко Юлія Олександрівна старший викладач кафедри сімейної та спеціальної педагогіки і психології, ДЗ «ПНПУ ім. К. Д. Ушинського», вул. Старопортофранківська 26, м. Одеса, 65020, тел.: (097) 399-92-38, e-mail: yuliatubichko@gmail.com, https://orcid.org/0000-0002-6569-8564

\title{
ФОРМУВАННЯ КОМУНІКАТИВНОӦ КОМПЕТЕНТНОСТІ У ДІТЕЙ 5-6 РОКІВ З ЗАГАЛЬНИМ НЕДОРОЗВИНЕННЯМ МОВЛЕННЯ
}

Анотація. Статтю присвячено питанням вивчення комунікативної компетентності у дітей 5-6 років з загальним недорозвиненням мовлення, спілкування, його особливостей, а також визначення напрямів подальшого корекційного впливу 3 метою формування комунікативної компетентності у дітей 5-6 років з ЗНМ III рівня. Аналіз наукових джерел показав що, дана проблема належить до числа найбільш значущих і недостатньо розроблених в теорії і практиці логопедії. У освітній практиці відсутня цілеспрямована робота 3 розвитку умінь, необхідних для участі дітей в процесі комунікації і набуття умінь і навичок необхідних для формування комунікативної компетентності. Доведено, що у дітей 5-6 років із ЗНМ недостатньо розвинені комунікативні уміння, низький ступінь активності в спілкуванні, що ускладнює контакти дитини 3 довколишніми, чинить негативний вплив на іiі психічний i особистісний розвиток і викликає труднощі при формуванні комунікативної компетентності.

Результати констатувального етапу експерименту дозволили визначити особливості спілкування дітей старшого дошкільного віку із ЗНМ і фактори, що їх характеризують. Експериментальне дослідження показало, що у дітей 3 загальним недорозвиненням мовлення низький рівень розвитку комунікативних умінь, що виявляється в обмеженості мовленнєвих та немовленнєвих засобів спілкування, труднощі їх реалізації, в недостатній мотиваційно-потребнісній сфері, цілеспрямованості, зниженні активності в спілкуванні, не визначеності форм спілкування, відповідних нормальному онтогенезу. Отримані результати довели, що при порушенні мовленнєвого розвитку поряд 3 формуванням вимовних навичок, лексичного запасу, граматичного ладу, необхідно передбачити спеціальні вправи, які дозволяють підвищити ефективність подолання ЗНМ. Це дозволило розробити змістову, методичну та організаційну сторони корекційної-педагогічного впливу, спрямованого на формування комунікативних умінь, а отже і комунікативної компетентності дітей із ЗНМ.

Ключові слова: комунікація, загальне недорозвинення мовлення, комунікативна компетентність, спілкування, мовлення, комунікативні уміння. 
Tubychko Yulia Oleksandrivna Senior Lecturer of the Department of Family and Special Pedagogy and Psychology, State Educational Institution «PNPU named after KD Ushinsky», Staroportofrankivska St., 26, Odessa, 65020, tel.: (097) 399-92-38, e-mail: yuliatubichko@gmail.com, https://orcid.org/0000-0002-6569-8564

\title{
FORMATION OF COMMUNICATIVE COMPETENCE IN CHILDREN 5-6 YEARS OLD WITH GENERAL SPEECH UNDER DEVELOPMENT
}

\begin{abstract}
The article is devoted to the formation of communicative competence in children 5-6 years old with general speech underdevelopment, the study of communication, its features, as well as the determination of directions for further corrective action in order to form communicative competence in children 5-6 years old with general speech underdevelopment of the III level. Analysis of scientific sources showed that this problem is one of the most significant and insufficiently developed in the theory and practice of speech therapy. In the practice of teaching, there is no purposeful work to develop the skills necessary for the participation of children in the communication process. It has been proven that children 5-6 years old with general speech underdevelopment have insufficiently developed communication skills, a low degree of activity in communication, which complicates the child's contacts with others, has a negative impact on his mental and personal development and causes difficulties in the formation of communicative competence.
\end{abstract}

The results of the ascertaining stage of the experiment made it possible to determine the peculiarities of communication among older preschool children with general speech underdevelopment and their determining factors. Experimental research has shown that children with general speech underdevelopment have a low level of development of communication skills, manifested in the limited speech and non-speech means of communication, difficulties in their implementation, in an insufficient motivational and need-based sphere, purposefulness, decreased activity in communication, the lack of formation of forms of communication corresponding to normal ontogeny. The results obtained proved that in case of impaired speech development, along with the formation of pronunciation skills, vocabulary, grammatical structure, it is necessary to provide special exercises to increase the effectiveness of overcoming the general underdevelopment of speech. This made it possible to develop the content, methodological and organizational aspects of correctional education aimed at the formation of the communicative competence of children with general speech underdevelopment.

Keywords: communication, general speech underdevelopment, communicative competence, communication, speech, communicative skills.

Постановка проблеми. Своєчасне оволодіння правильною мовою i набуття комунікативної компетентності має важливе значення для формування повноцінної особистості дитини, гармонійного психофізичного розвитку, успішного подальшого навчання і соціалізації. У зв'язку з цим підвищений 
інтерес у педагогів і психологів викликають діти дошкільного віку із загальним недорозвиненням мовлення, оскільки мовлення як засіб комунікації виникає i розвивається в процесі спілкування. Порушення мовленнєвої функції не може не позначитися негативно на розвитку процесу комунікації у дитини.

Недорозвинення мовленнєвих засобів знижує рівень спілкування, сприяє виникненню психологічних особливостей (замкнутості, боязкості, нерішучості, сором'язливості); породжує специфічні риси загальної та мовленнєвої поведінки (обмежену контактність, сповільнену залученість до ситуації спілкування, невміння підтримувати бесіду, дослухатися до висловлювань інших, неуважність до мовлення співрозмовника та його змісту), все це призводить до зниження комунікативної активності. Існує i зворотна залежності - при недостатньому спілкуванні темп розвитку мовлення та інших психічних процесів сповільнюється. Відтак, недосконалість комунікативних умінь, мовленнєва інактивність не забезпечують процес вільного спілкування $\mathrm{i}$, в свою чергу, не сприяють розвитку мовленнєво-мисленнєвої та пізнавальної діяльності дітей, перешкоджаючи тим самим оволодінню знаннями.

Аналіз останніх досліджень і публікацій. В останні десятиліття проведено ряд досліджень, спрямованих на вивчення дітей із загальним недорозвиненням мовлення (Г. Бабіна, О. Грибова, Г. Гуменна, О. Дзюба, М. Лісіна, О. Мастюкова, Л. Соловйова, Л. Халілова, Г. Чиркіна, Т. Шаховська, А. Ястребова та ін.). Автори вказують на стійкі лексико-граматичні та фонетико-фонематичні порушення, відсутність зв'язного мовлення, незрілість окремих психічних функцій у дітей 3 різними видами недорозвинення мовлення. Ці порушення ускладнюють спонтанне формування мовленнєвих умінь, навичок i, як результат, комунікативної компетентності, інколи взагалі унеможливлюючи їі становлення.

Учені відзначають, що діти відчувають труднощі при програмуванні висловлювання, синтезуванні окремих елементів в структурне ціле, відборі мовленнєвого матеріалу для тієї чи іншої мети (В. Воробйова, Т. Волковська, Г. Гуменна, Л. Спірова, Т. Філічьова, С. Шаховська та ін.). Учені відзначають, що несформованість мовленнєвої бази, як найважливішої передумови спілкування, ускладнює його перебіг. Труднощі спілкування проявляються в несформованості основних форм комунікації (В. Воробйова, О. Дзюба, О. Мастюкова), змішуванні ієрархії мети спілкування (О. Грибова), зниженні потреби в ньому (А. Матюшкін, Л. Соловйова, Г. Чиркін, Г. Юсупова). Недостатність вербальних засобів спілкування ускладнює взаємодію між дітьми, стає перешкодою у формуванні ігрового процесу (Л. Соловйова, Е. Харитонова).

Разом 3 тим, недостатньо досліджень, що показують залежність процесу формування комунікативної компетентності від ступеня сформованості мовленнєвих засобів і комунікативних умінь дітей дошкільного віку із ЗНМ, не створена система спеціальних занять, орієнтована на формування у них комунікативної компетентності, що вимагає пошуку шляхів підвищення ефективності логопедичної роботи з дітьми старшого дошкільного віку із ЗНМ. 
Мета статті - дослідити специфіку комунікативної компетентності у дітей 5-6 років з загальним недорозвиненням мовлення III рівня і визначити основні напрями подальшої корекційно-педагогічної роботи щодо іï формування.

Виклад основного матеріалу. Процес становлення мовлення залежить від багатьох факторів: фізичного розвитку дитини, стану іiі нервової системи, особливостей вищої нервової діяльності, впливу навколишнього мовленнєвого середовища. Мовлення є засобом і формою спілкування, знаряддям мислення і пізнавальною діяльністю, засобом організації і регуляції психічних процесів. У багатьох дослідженнях встановлено, що психічні процеси - сприйняття, мислення, пам'ять, увага, уява - опосередковані мовленням (Л. Виготський, М. Жинкін, А. Запорожець, О. Леонтьєв, О. Лурія, А. Люблінська).

Відомо, що комунікація здійснюється на основі ряду функцій, які реалізуються завдяки мовленню, тому Л. Виготський виділяє дві основні функції мовлення: спілкування і узагальнення. В них проявляється все різноманіття тих функцій, які мовлення виконує на різних етапах розвитку дитини в різних ситуаціях комунікації [4]. Розвиваючи ідею Л. Виготського про соціальне походження мовлення, С. Рубінштейн зазначає, що «є дві основні функції мовлення - комунікативна та сигнітивна, внаслідок чого мовлення $є$ засобом спілкування і формою існування думки, свідомості, які формуються одна через іншу і функціонують одна в іншій» [9, с. 34]. М. Лісіна називає три основні функції мовлення, в кожній 3 яких $є$ свої форми: 1) монологи, діалоги, бесіда кількох осіб; 2) мовлення, яке протікає у внутрішньому плані; 3) письмове мовлення, матеріалізоване в графічних символах і знаках [8].

О. Мастюкова, розглядаючи особливості мовленнєвого розвитку дітей 3 мовленнєвими порушеннями, зіставляє функції мовлення дітей 3 нормальним розвитком і при патології. Вона виділяє комунікативну, узагальнюючу та регулюючу функції мовлення. Комунікативна функція мовлення як засіб спілкування дитини з дорослими лежить в основі всього вербального розвитку. Від своєчасної появи цієї функції залежить, як скоро дитина опанує вищими рівнями свідомості і довільності поведінки. Узагальнююча функція мовлення виступає як засіб мислення. Слово, узагальнюючи предмети, слугує предметом абстракції. Дитина опановує поняттями, вибудовує класифікації, робить висновки, аналізує явища навколишньої дійсності відповідно до віку. Комунікативна та узагальнююча функції мовлення формуються в тісній єдності, оскільки за допомогою мовлення дорослих дитина отримує нову інформацію, потім, використовуючи іiі в своєму мовленні, засвоює iї, активізуючи при цьому розумові операції. Регулююча функція мовлення виникає до кінця дошкільного віку. Вона є засобом регуляції вищих психічних функцій. Дитина, сприймаючи мовленнєві інструкції, може зосередити увагу на більш значущому, цікавому для неї. Зосередження пам'яті дозволяє запам'ятати більшу кількість інформації. Перехід зовнішнього мовлення у внутрішнє дозволяє осмислити ситуацію і дати інструкцію, команду, прохання, 
наприклад, однолітку з приводу виконання діяльності, тобто передати план дій [7].

Як вже зазначалося, вирішальну роль в становленні і використанні мовлення дитиною відіграють чинники комунікативного характеру, бо виникнення і розвиток мовлення у дітей відбувається, головним чином, у процесі їх спілкування 3 довколишніми людьми. Дитина починає говорити тільки в ситуації спілкування і тільки на вимогу дорослих. Про це свідчать факти затримки і відсутності мовленнєвого розвитку у дітей при дефіциті спілкування, важкого недорозвинення мовлення дітей, які виросли в ізоляції від людського суспільства.

Відзначимо, що недосконалість мовленнєвих умінь i навичок, не забезпечуючи необхідного структурного та смислового оформлення висловлювання, $\epsilon$, у свою чергу, базою для подальшого мовленнєвого розвитку, що накладає відбиток на формування основної функції мовлення комунікативної. Оскільки мовлення пов'язане з усіма психічними процесами, то його недорозвинення проявляється також у порушенні пізнавальної, узагальнюючої та регулюючої функцій. Так, порушення комунікативної функції не дозволяє сформуватися узагальнюючій функції, оскільки мовленнєві здібності дітей із ЗНМ не дають можливості правильно сприймати інформацію та розширювати їі при спілкуванні з довколишніми.

М. Жінкін [6] вважає, що затримка одного компонента, у разі - мовлення, веде до затримки розвитку другого - мислення. Дитина, яка не володіє відповідно до віку поняттями, узагальненнями, класифікаціями, не може виконувати аналіз і синтез інформації, що надходить. Дефекти розвитку мовлення затримують формування пізнавальної функції мовлення, що не повною мірою може виступати засобом передачі, способом реалізації соціального досвіду, засобом мислення. Дитині зрозуміла лише інформація, пов'язана зі звичною, знайомою ситуацією, предметами та людьми, що наочно сприймаються і безпосередньо знайомі. Передача нових знань, відомостей, особистих переживань неможлива, дитина не може сформулювати та за допомогою мовлення передати свої думки.

Все це призводить до труднощів опанування компетентностей передбачених вимогами стандартів i програм дошкільної освіти. Так, у Базовому компоненті дошкільної освіти зазначено, що комунікативна компетентність - здатність дитини до спілкування з однолітками і дорослими у різних формах конструктивної взаємодії; здатність підтримувати партнерські стосунки, заявляти про свої наміри і бажання, узгоджувати свої інтереси 3 іншими, домовлятися, за потреби аргументовано відстоюючи свою позицію [1].

Особливого значення дослідження комунікативної компетентності набуває стосовно дітей старшого дошкільного віку, який характеризується, з одного боку, активним включенням дитини в групову комунікативну взаємодію 3 однолітками, 3 іншого - збагаченням досвіду спілкування 3 дорослими, що сприяє формуванню комунікативної готовності до шкільного навчання й подальшої ii соціалізації (Ю. Бистрова, К. Островська, Ю. Приходько, 
Л. Руденко, Т. Сак, В. Синьов, С. Синьова, Л. Фомічова).

Звісно, формування комунікативної компетентності дитини 3 ЗНМ детерміновано особливостями іiі порушення, тому слушним $\epsilon$ визначення пропоноване О. Дзюбою, згідно 3 яким, комунікативна компетентність дошкільників з ЗНМ - це сукупність знань, умінь і навичок, що забезпечують ефективність перебігу процесів спілкування (оволодіння навичками вербального спілкування, сприйняття, оцінки та інтерпретації комунікативних дій, планування ситуації спілкування), з врахуванням специфіки перебігу мовленнєвого порушення, у тому числі його впливу на мотиваційну сферу (зміна ціннісних орієнтацій та установок особистості, формування комунікативної культури), а також правил регулювання комунікативної поведінки дошкільника та засобів його виправлення [5].

Вивчення та аналіз психолого-педагогічної літератури показують, що у дітей з ЗНМ на фоні системних мовленнєвих розладів затримується розвиток психічних процесів, комунікативні навички не формуються або формуються на низькому рівні. Їх недосконалість не забезпечує процесу спілкування, а тому не сприяє розвитку мовленнєво-мисленнєвої та пізнавальної діяльності, перешкоджає оволодінню знаннями, комунікативним досвідом, що визначає рівень комунікативної компетентності.

Можна виділити особливості комунікативної компетентності дітей 5-6 років із загальним недорозвиненням мовлення, які передбачають наявність розгорнутого фразового мовлення 3 елементами недорозвинення лексики, граматики та фонетики; характеризується неточним розумінням i використанням узагальнюючих понять, слів з узагальнюючим і абстрактним значенням; словниковий запас нижчий, ніж у дітей без патології мовлення; труднощі у відтворенні слів і словосполучень складної складової будови; недостатня диференціація звуків на слух; низька мовленнєва активність і недостатня критичність до свого дефекту; порушення фонематичного сприйняття; відзначаються порушення комунікативної функції - зниження потреби в спілкуванні, не сформованість способів спілкування (діалогічне та монологічне мовлення), відсутність інтересу до контактів, невміння орієнтуватися в ситуації спілкування та негативізм [2].

Започатковуючи експериментальне дослідження формування комунікативної компетентності у дітей 5-6 років з загальним недорозвиненням мовлення, ми спирались на праці Т. Волковської, О. Дзюби та Л. Соловйової та виходили із загальних закономірностей розвитку спілкування у дітей 3 нормальним мовленнєвим розвитком.

Оскільки в рамках пропонованого дослідження неможливо схарактеризувати всі знання, уміння і навички, що забезпечують ефективність перебігу процесів спілкування і формують комунікативну компетентність, то ми завданнями дослідження обрали найбільш інформативні аспекти: 1) вивчення мовленнєвих засобів та форм комунікації i аналіз їх взаємозалежності у дітей; 2) дослідження ступеня активності спілкування дітей 
3 дорослими i в різних видах діяльності; 3) вивчення особистісних особливостей та поведінки дітей з ЗНМ III рівня.

В експерименті взяли участь 60 дітей. Експериментальна група була сформована 330 дітей, які відвідують мовленнєві групи ЗДО № 228, м. Одеси і мають висновок медико-психолого-педагогічної комісії про наявність у них загального недорозвинення мовлення III рівня. Динамічне спостереження за дітьми підтвердило цей висновок. За висновком окуліста і отоларинголога всі діти були зі збереженим зором i слухом, також всі дошкільники були кваліфіковані психоневрологом, як діти 3 нормальним інтелектуальним розвитком. Середній вік випробовуваних на момент початку експерименту склав 6 років. Для порівняльного аналізу в дослідження було включено група дітей, яку склали 30 однолітків 3 нормальним мовленнєвим розвитком, які відвідують ЗДО №175, м. Одеси.

Процедура проведення дослідження передбачала наявність комунікативного завдання для випробуваного, забезпечення спеціальних для спілкування умов, відповідність завдань віковим інтересам і пізнавальним можливостям дітей.

Попередній аналіз мовлення дітей довів, що всі діти із ЗНМ відчували труднощі при звуковимові, у них були фонематичні порушення, спрощення i спотворення складової структури слова: перестановки, уподібнення складів тощо. Лексична недостатність проявлялася в бідності і недиференційованості словникового запасу. Відзначалися обмеження можливостей i мала різноманітність в мовленні прикметників та прислівників; мали місце неправильне вживання слів за значенням, незнання окремих слів, заміна однієї назви іншою на основі їх смислового зближення, були відсутні узагальнюючі поняття, спостерігалися помилки при вживанні просторових і часових уявлень. Діти не використовували синоніми, антоніми. Морфологічні порушення проявлялись в порушеннях словозміни i словотворення. Відзначалися структурні і семантичні аграматизми. Дітям важко було при розумінні та оформленні складних мовленнєвих конструкцій, для них було характерно непослідовне, неповне, нелогічне викладання думок, виявлялись значні труднощі при побудові власного зв'язного висловлювання. Ці особливості різного ступеню прояву перешкоджали повноцінному спілкуванню дітей.

Реалізація завдань дослідження здійснювалася поетапно. Кожен етап включав серію експериментальних завдань. На першому етапі вивчалися мовленнєві засоби в різних ситуаціях комунікації.

Для дослідження засобів комунікації дітям пропонувалися такі експериментальні завдання:

1. Відтворення добре знайомого тексту (казка за вибором дитини). Експериментатор пропонував дитині розповісти знайому казку. Дане завдання буле спрямовано на відтворення дітьми добре засвоєного ними, щодо смислової передачі змісту, побудови зв'язного, послідовного повідомлення, перевірки можливостей засвоєння дитиною мовленнєвих зразків, визначення 
Журнал«Герспективитаінновації наукиљ

(Серія«Гедагогіка»), Серія«ГТихологія», Серія «Медицина»

№5(5) 2021

ступеня самостійності при переказі знайомого матеріалу, а також визначення особливостей конструювання фраз, лексичних одиниць при реалізації висловлювання.

2. Відтворення незнайомого тексту двічі прочитаного експериментатором (казка). Дитині пропонувалося прослухати казку, яка читалась двічі, а потім іiі розповісти. Якщо дитина не могла самостійно виконати завдання, то експериментатор допомагав їй навідними питаннями та уточненнями.

3. Закінчення розповіді за запропонованим початком. Дане завдання мало на меті дослідити можливості дітей з ЗНМ в складанні оповідань 3 елементами творчості. Дитині пропонувався початок (якби я потрапив у казку... лист до святого Миколая... коли я стану дорослим...), а вона мала придумати його продовження. Експериментатор: «Давай придумаємо оповідання. Я почну, а ти продовжуй: «Напередодні Дня святого Миколая всі діти загадують бажання i пишуть листа...».

Вибір завдань був зумовлений тим, що вони найчастіше використовуються на заняттях з розвитку у дітей зв'язного мовлення, також ці завдання були різного рівня складності щодо самостійної побудови дітьми висловлювання, а також тим, що вони представляли собою різні комунікативні ситуації.

При аналізі усних висловлювань дітей ми враховували такі показники:

1) комунікабельність дитини (бажання виконати завдання, активність спілкування, легкість контактування);

2) експресивність спілкування: використання міміки, пантоміміки та ін. невербальних проявів, емоційний стан, інтонаційна виразність;

3) ступінь самостійності, використання допомоги при виконанні завдань;

4) повнота викладу, змістовна відповідність відтвореного матеріалу заданому зразку, зв'язність і логічність висловлювання;

5) мовленнєві засоби, за допомогою яких реалізовувалися висловлювання дітей: лексична повнота і граматична правильність фрази, типи речень.

Названі показники послужили критеріями оцінки мовленнєвих засобів спілкування досліджуваних дітей і мали бальну систему оцінки. Вища оцінка виконання завдання дорівнювала 3 балам.

Високий рівень (3 бали) - повний, самостійний, логічний виклад матеріалу, точність, повнота використання лексики, наявність правильно оформлених простих поширених і складних речень, інтонаційна виразність.

Достатній (2 бали) - окремі неточності, труднощі у відтворенні тексту, поодинокі аграматизми, незначна допомога у вигляді підказок.

Низький (1 бал) - порушення в структуруванні тексту, необхідність допомоги 3 боку експериментатора, бідність, неточність лексики, грубі аграматизми; 0 - відмова виконувати завдання.

Дані щодо використання дітьми експериментальної групи (ЕГ) i контрольної групи (КГ) засобів комунікації представлені на рис. 1. 


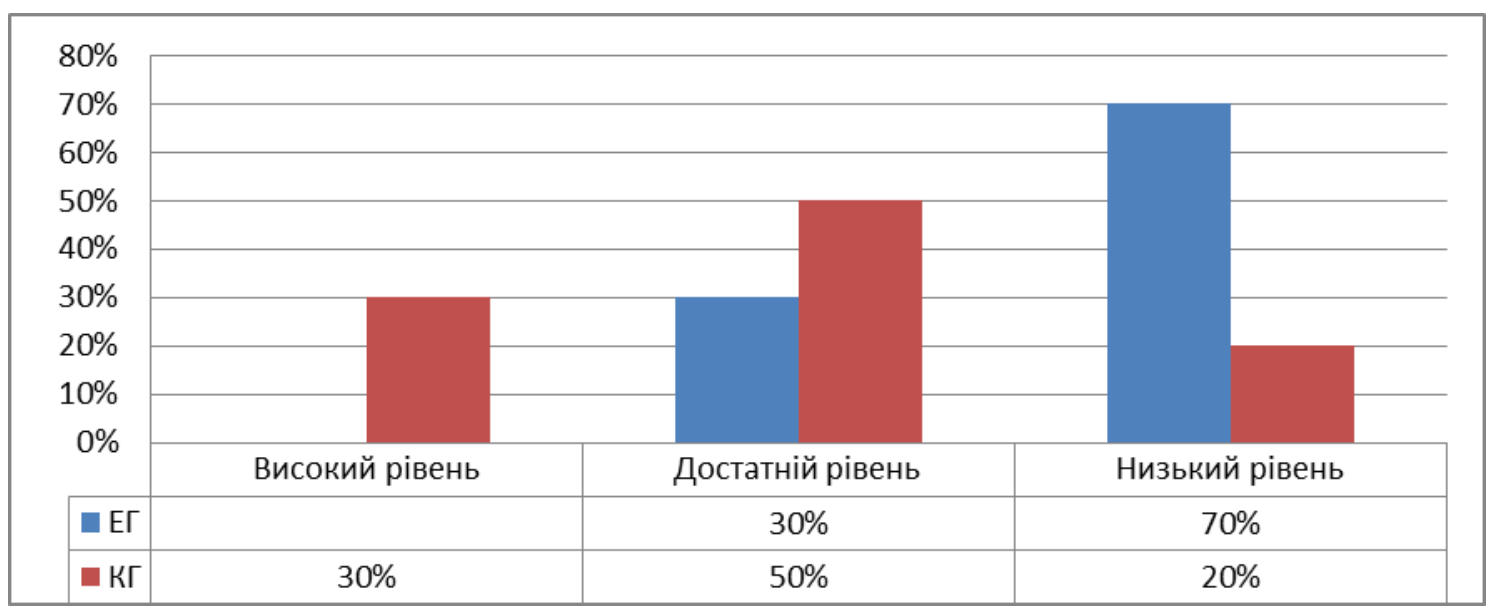

Puс. 1. Використання засобів комунікаиії дітьми ЕГ і КГ (у\%)

Як бачимо на рис. 1, високий рівень зафіксовано у 30\% дітей КГ (діти 3 нормальним мовленнєвим розвитком), в ЕГ (діти з ЗНМ III рівня) таких дітей не було. Достатній рівень відзначено у $30 \%$ дітей ЕГ і $50 \%$ дітей КГ, на низькому рівні перебували 70\% ЕГ і 20\% КГ.

Під час виконання завдань діти ЕГ вели себе по-різному, часто ніяковіли, шарпали одяг, сиділи в напруженій позі, відводили погляд убік. Для переказів дітей ЕГ була характерна тенденція до вживання простих за структурою конструкцій: простих поширених речень при дефіциті складно організованих висловлювань, відзначалася висока кількість непоширених речень. У переказах відзначалися порушення послідовності викладу, перестановки фрагментів тексту, пропуски окремих моментів дії, смислова невідповідність тексту казки, відсутність деяких персонажів, недотримання зв'язності викладу. Зустрічалися помилки, пов'язані з недостатнім розумінням лексичного значення слів, слабкістю лексико-семантичних диференціювань. Отримані дані свідчать про значні труднощі дітей з ЗНМ при відтворенні навіть простого, добре знайомого їм тексту за змістом викладу, структуруванням тексту i застосуванням мовленнєвих засобів.

Виконання запропонованих завдань дітьми КГ суттєво відрізнялося від однолітків ЕГ. Так, переважна більшість дітей (80\%) впоралися із поставленим завданням. Вибір казки для переказу відрізнявся різноманітністю і варіативністю. Діти відтворювали текст більш складних казок, як в змістовному плані, так і мовленнєвому оформленні.

Другий етап дослідження був спрямований на визначення рівнів сформованості спілкування у дітей 5-6 років із ЗНМ III рівня. Дітям пропонували на вибір три типи взаємодії: ігри 3 дидактичними іграшками, читання і обговорення книг, бесіда на особистісні теми з дорослим. Тривалість гри, читання, бесіди не перевищувала 10 хвилин. Дослідження проводилося індивідуально. Ці експериментальні ситуації моделювали практичне, пізнавальне, особистісне спілкування і відповідали ситуативно-діловій, 
Журнал«ГЕрспективита іновації науки»

(Серія «Гедагогіка», Серія «Гиихологія», Серія «Медицина»

№5(5) 2021

позаситуативно-пізнавальній, позаситуативно-особистісній формам комунікації.

При дослідженні відзначалися порядок вибору ситуацій, основний об'єкт уваги в перші хвилини досліду (іграшки, книги, дорослий), контактність дитини, рівень комфортності під час експерименту, особливості їі поведінки, аналіз мовленнєвих висловлювань (ситуативні, позаситуативні, несоціальні, соціальні), максимальна тривалість діяльності (за бажанням дитини, але не більше 10 хвилин). Якщо дитина вибирала першу, другу, третю ситуації, то враховувалась тривалість тієї чи іншої ситуації, загальна активність, характер висловлювань дитини, іiі емоційний стан. При труднощах дитини у виборі, дорослий пропонував послідовно пограти, почитати і поговорити.

Таким чином, для більш точного визначення рівня розвитку спілкування здійснювалися всі три види взаємодії з кожною дитиною. На основі вибору дитини та порівняльного аналізу пї активності в різних ситуаціях робився висновок про домінуючі форми спілкування. Участь дорослого в кожній ситуації виражалась доброзичливістю до дитини, готовністю прийти на допомогу, бажанням спілкуватися з нею.

Відповідно до вищезазначених характеристик, було визначено рівні сформованості спілкування.

Високий рівень (3 бали) - дитина контактна, почувається комфортно, рівний емоційний стан, діалогічні репліки відповідають ситуації, використовує висловлювання різних типів: ситуативні, позаситуативні, несоціальні, соціальні, мовленнєві висловлювання повні, самостійні, логічний виклад матеріалу, точність, повнота використання лексики, наявність правильно оформлених простих поширених і складних речень, інтонаційна виразність.

Достатній (2 бали) - активність знижена чи, навпаки, дитина надто збуджена, важко іде на контакт, відзначаються окремі неточності, труднощі у побудові діалогу, репліки ситуативні, вагається при виборі теми, початку i підтримці бесіди, при відтворенні тексту, поодинокі аграматизми, незначна допомога у вигляді підказок і заохочень.

Низький (1 бал) - відмова від спілкування, значні труднощі в побудові діалогу, підвищена збудливість, неконтактність, зниження уваги, порушення в структуруванні тексту, необхідність значної допомоги 3 боку експериментатора, бідність, неточність лексики, грубі аграматизми; 0 балів відмова від виконання завдання.

Результати виконання дітьми ЕГ і КГ завдань другого етапу дослідження представлені на рис. 2. 


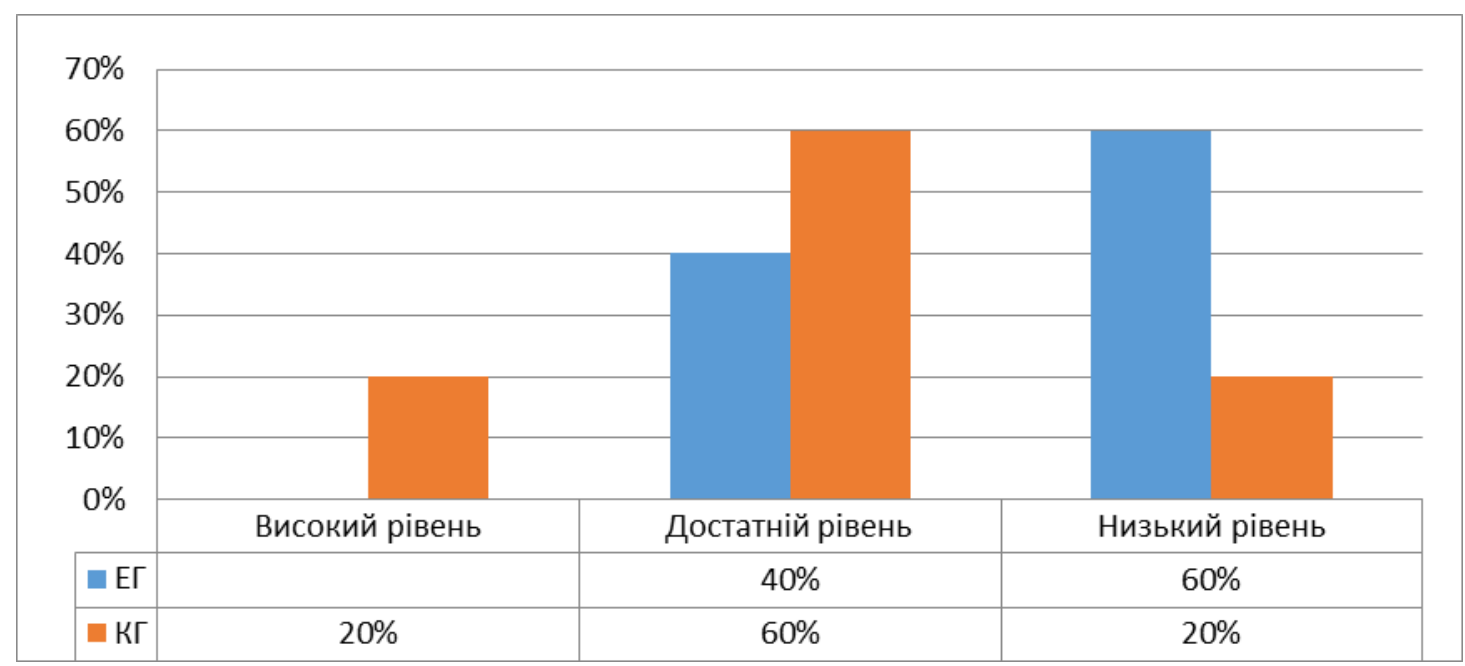

Pис. 2. Визначення рівнів сформованості спілкування у дітей ЕГ і КГ (у \%)

Результати даної серії експерименту показали наступне: високий рівень визначено тільки у 20\% дітей КГ, достатній - у 40\% дітей ЕГ і $60 \%$ дітей КГ, переважна більшість дітей ЕГ (60\%) знаходиться на низькому рівні сформованості спілкування, тоді як в КГ на цьому рівні опинилось тільки $20 \%$ дітей.

Для мовлення дітей 3 ЗНМ III рівня характерні такі особливості: найчастішою вживаною категорією були іменники і дієслова. Бесіда 3 дорослим на особисті теми виявилася найменш привабливою ситуацією для дітей. Пропозиція поговорити викликала у них здивування, занепокоєння, інколи вони взагалі відмовлялися від комунікації. Поведінка піддослідних у цих комунікативних ситуаціях свідчила про їхнє збентеження, труднощі налагодження комунікації. Діти були малоактивні, не впевнені, боязкі, неініціативні і неуважні, малоговіркі і напружені у спілкуванні. Вони зазнавали труднощів при реалізації поставленого завдання. У їхніх нечисленних висловлюваннях відзначалися бідність та одноманітність мовленнєвих засобів, структурний, морфологічний аграматизм, порушення синтаксичної організації висловлювання, численні паузи, вони потребували активної допомоги з боку експериментатора. Мовлення дітей відрізнялося незакінченістю, незавершеністю думки, що передається, часто спостерігалося повернення до раніше сказаного. Діти, здебільшого, не прагнули досягти результату під час виконання завдання.

У дітей КГ таких проблем не спостерігалось, здебільшого вони 3 задоволенням вступали в бесіду, жваво розповідали і обговорювали пропоновані теми завдань. У більшості дітей КГ мовлення відрізнялось логічністю викладу, правильністю і завершеністю.

За результатами констатувального етапу експерименту ми визначили основні напрями корекційно-педагогічної роботи для формування комунікативної компетентності у дітей 5-6 років з ЗНМ III рівня:

1) розвиток зв'язного мовлення, лексичної та граматичної його сторони;

2) формування комунікативних умінь і навичок; 
3) мотиваційне залучення до мовленнєвого висловлювання;

4) опанування сприйняття, оцінки та інтерпретації комунікативних дій співрозмовника, планування ситуації спілкування;

5) розвиток словесно-логічних компонентів мовленнєвої діяльності та довільного мовлення;

6) формування мовленнєвої компетенції дитини;

7) покращення регуляції сенсомоторної діяльності;

8) включення дошкільників 3 ЗНМ у різні форми ознайомлення 3 комунікативними навичками;

9) відпрацювання технологій взаємодії в різних ситуаціях спілкування i розвиток готовність до спілкування;

10) підвищення самостійності в оволодінні комунікативними навичками i формування комунікативної культури.

Висновки. Таким чином, аналіз отриманих в ході експерименту даних дозволив говорити про наявність особливостей комунікації дітей старшого дошкільного віку із ЗНМ: діти відзначалися низьким рівнем вербальної комунікативної активності; не проявляли ініціативи, відчували комунікативні труднощі; переважна кількість контактів дітей носила ситуативний характер, що свідчить про бідність знань дітей, недостатню сформованість їхнього контекстного мовлення; вони найчастіше вибирали i довше підтримували ігрову взаємодію з дорослими, воліли уникнути позаситуативного спілкування.

Таким чином, комунікативні можливості дітей iз загальним недорозвиненням мовлення відрізнялися помітною обмеженістю і за всіма основними параметрами виявили значне відставання від норми. Засновуючись на цих даних, результатах попередніх досліджень і аналізі літератури ми визначили основні напрями корекційно-педагогічної роботи спрямованої на формування комунікативної компетентності у дітей 5-6 років з загальним недорозвиненням мовлення III рівня.

\section{Лimepamypa:}

1. Базовий компонент дошкільної освіти. Державний стандарт дошкільної освіти: нова редакція. Наказ МОН України №33 від 12.01.2021.

2. Волковская Т.Н., Юсупова Г.Х. Психологическая помощь дошкольникам с общим недоразвитием речи. Москва: Книголюб, 2014. 388 с.

3. Воробьева В.К. Методика развития связной речи у детей с системным недоразвитием речи. Москва: Єксмо, 2006. 310 с.

4. Выготский Л.С. Основы дефектологии. Санкт-Петербург: Лань, 2013. 656 с.

5. Дзюба О.В. Развитие коммуникативной компетентности дошкольников с общим недоразвитием речи: дис. ... канд. пед. наук: 13.00.07 / Московский государственный гуманитарный ун-тет им. М.А. Шолохова. Москва, 2009. 244 с.

6. Жинкин Н.И. Язык - речь - творчество. Избранные труды. Москва: Лабиринт, 1998. 365с.

7. Жукова Н.С., Мастюкова Е.М., Филичева Т.Б. Логопедия. Преодоление общего недоразвития речи у дошкольников. Екатеринбург: АРД ЛТД, 1998. 320 с.

8. Лисина М.И. Формирование личности ребенка в общении; 2-е изд. Санкт-Петербург: Питер, 2009. 320 с.

9. Рубинштейн С. Я. Психология умственно отсталого ребенка: 4-е изд., перераб. и доп. Москва: Просвещение, 1998. 196 с. 


\section{References:}

1. Bazovyy komponent doshkil'noyi osvity. Derzhavnyy standart doshkil'noyi osvity: nova redaktsiya (2021). Nakaz MON Ukrayiny №33 vid 12.01.2021. [in Ukrainian].

2. Volkovskaya, T.N. \& Yusupova, G.KH. (2014). Psikhologicheskaya pomoshch' doshkol'nikam s obshchim nedorazvitiyem rechi [Psychological assistance to preschoolers with general speech underdevelopment]. Moscow: Knigolyub [in Russian].

3. Vorob'yeva, V.K. (2006). Metodika razvitiya svyaznoy rechi u detey s sistemnym nedorazvitiyem rechi [Methodology for the development of coherent speech in children with systemic speech underdevelopment]. Moskva: Eksmo [in Russian].

4. Vygotskiy, L.S. (2013). Osnovy defektologii [Fundamentals of defectology]. SanktPeterburg: Lan' [in Russian].

5. Dzyuba, O.V. (2009). Razvitiye kommunikativnoy kompetentnosti doshkol'nikov s obshchim nedorazvitiyem rechi [Development of communicative competence of preschoolers with general speech underdevelopment]: Candidate's thesis. Moskva: Moskovskiy gosudarstvennyy gumanitarnyy un-tet im. M.A. Sholokhova [in Russian].

6. Zhinkin, N.I. (1998). YAzyk - rech' - tvorchestvo. Izbrannyye trudy [Language - speechcreativity]. Moskva: Labirint [in Russian].

7. Zhukova, N.S., Mastyukova, Ye.M., \& Filicheva, T.B. (1998) Logopediya. Preodoleniye obshchego nedorazvitiya rechi u doshkol'nikov [Speech therapy. Overcoming the general speech underdevelopment in preschoolers]. Yekaterinburg: ARD LTD [in Russian].

8. Lisina, M.I. (2009). Formirovaniye lichnosti rebenka $v$ obshchenii [Formation of the child's personality in communication]; 2-ye izd. Sankt-Peterburg: Piter [in Russian].

9. Rubinshteyn, S. YA. (1998)/ Psikhologiya umstvenno otstalogo rebenka [Psychology of a mentally retarded child]: 4-ye izd., pererab. i dop. Moskva: Prosveshcheniye [in Russian]. 